\title{
Development of Validation Instrument for Interactive Multimedia Learning Implementation Plan
}

\author{
Kukuh Andri Aka \\ Elementary School Teacher Education \\ Universitas Nusantara PGRI Kediri \\ Kediri, Indonesia \\ kukuh.andri@unpkediri.ac.id
}

\author{
Sa'dun Akbar \\ Elementary School Teacher Education \\ Universitas Negeri Malang \\ Malang, Indonesia \\ sadun.akbar.fip@um.ac.id
}

\author{
Julian Sahertian \\ Universitas Nusantara PGRI Kediri \\ Kediri, Indonesia \\ juliansahertian@unpkediri.ac.id
}

\begin{abstract}
Being part of the development of interactive multimedia based on local wisdom and scientifically oriented learning as accommodation for character education in the alpha generation. To achieve these objectives, activities are carried out including: (1) formulating the theoretical aspects of the learning plan developed; (2) compiling instrument lattices; (3) arranging instrument items; (4) drafting scoring rubrics and instrument criteria; (5) conducting expert judgment; (6) revision and improvement of instruments. The following conclusion: (1) Based on theoretical studies, formulated the three aspects of theoretical base as the basic of the instrument, namely (a) the aspect of component implementation plan of learning, (b) the aspect of the principle of the implementation plan of learning, (c) the aspects of the stages of multimedia learning. (2) Based on the results of the content validation by the instrument expert can be concluded to be in a good category, and can be used.
\end{abstract}

Keywords - learning implementation plan, multimedia learning, interactive multimedia

\section{INTRODUCTION}

Based on data from Nielsen that conducts research on the use of media in Indonesian society shows that information technology-based media (ICT) is the main means used by Indonesian people [1]. All generations in Indonesian society cannot be separated from ICT-based media and it is represented in figure 1 and 2 . In connection with this, McCrindle (in Sterbenz) [2] added that alpha generation (births from 2010-2025) will be a generation that relies heavily on technology, exceeding the X genes (born 1981 to 2000) and $\mathrm{Z}$ genes (births from 1995-2010) Keep in mind, in Indonesia, the oldest alpha generation is currently in the lower class of elementary school (grades 1-3).

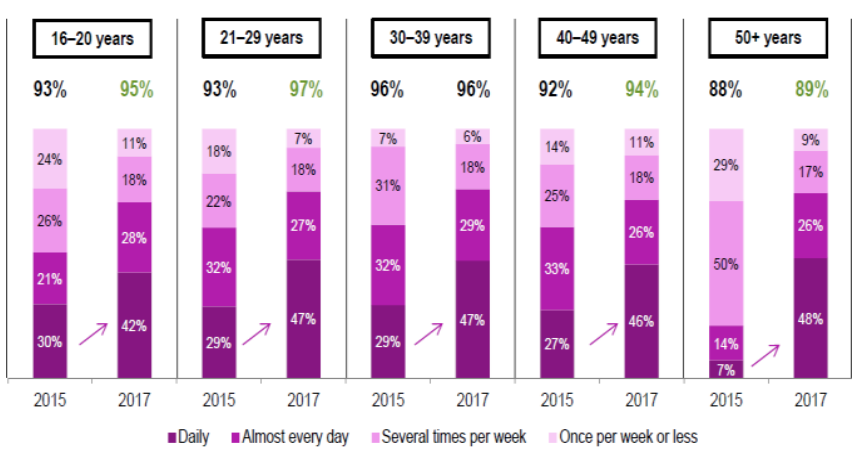

Fig. 1. Dual screen: TV and Internet (\% watch TV and use internet at the same time) (Source: Nielsen Media Consumer) [1]

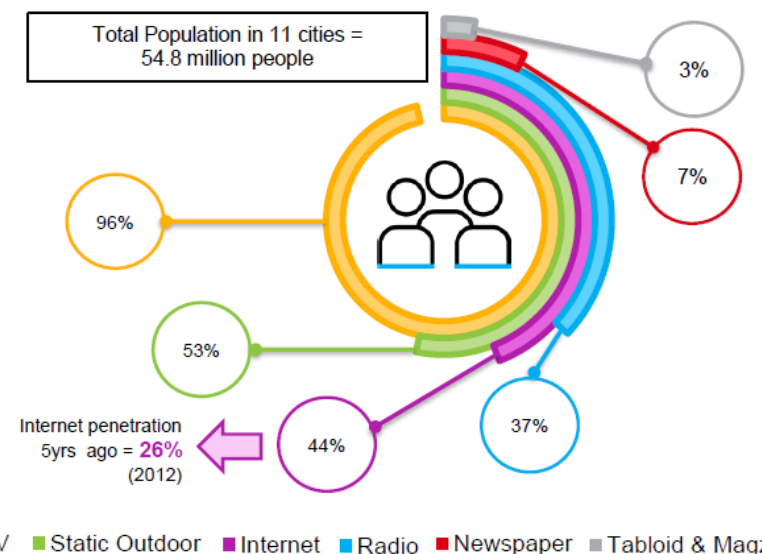

Fig. 2. Media Penetration: internet is now on 3rd position among all media with $44 \%$ reach or equivalent with 24.2 million people. (Source: Nielsen Media Consumer [1])

Therefore, the use of technology by alpha generation needs to be directed at positive things, such as giving positive content to technology facilities. A dependence and excessive interaction of children on technology can be colored with positive content, appropriate technology innovation is needed, for example, educational content embedded in ICT-based media [3].

At present, learning approaches that demand the use of ICT are very necessary. being part of the multimedia development of the above, it is necessary to develop an implementation plan to accompany the multimedia learning if used in the classroom. Before developing the learning plan, it is important to develop a validation instrument for learning implementation plans.

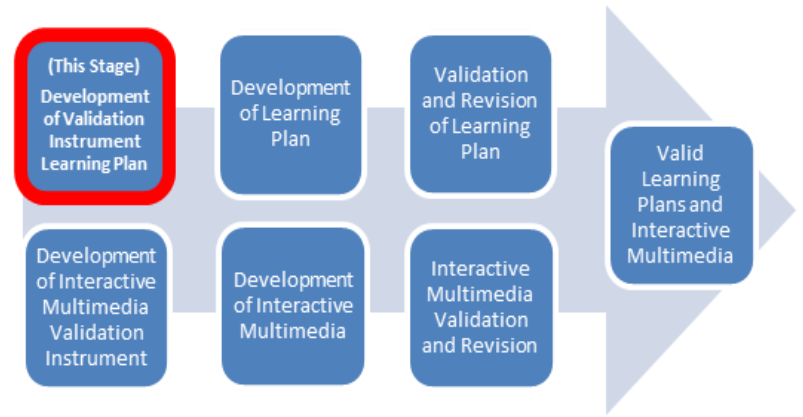

Fig. 3. Grand Design Research Map Development of Interactive Multimedia 
Based on the explanation above, the research at this stage aims to develop learning plan validation instruments. To ensure the implementation plan of this learning is in accordance with the interactive multimedia that is developed, the instrument of validation must be based on the aspects of (1) Minister of Education and Culture Regulation of the Republic of Indonesia Number 22 of 2016 concerning Standard Process of Primary and Secondary Education [4], and (2) five stages of cognitive theory multimedia learning [5].

Minister of Education and Culture Regulation of the Republic of Indonesia Number 22 of 2016 concerning process standards is the basic foundation in developing a learning implementation plan, in this chapter III of this regulation is regulated minimum components and the principle of preparing learning implementation plans that must be contained. Therefore, this validation instrument needs to contain these components and principles. In addition, so that the implementation plan of this learning is in accordance with interactive multimedia, then, the development of the learning implementation plan must contain five steps of cognitive multimedia learning theory according to Mayer [5].

Related to the validation process of learning implementation plans, it is necessary to have a validation instrument that will be developed in this study. The instrument is in the form of a questionnaire with non-test techniques. So that the questionnaire is valid and measures what should be measured, it needs to be tested for validity.

Kerlinger divided validity into three types, namely content validity, criteria validity, and construct validity [6]. For the use of non-test instruments that are compiled in narrative or nominal form, it is sufficient to do the content or construct validity [7]. In this study after the instrument was developed, only content validity was carried out. Content validity is intended to determine the suitability of the contents of a measuring instrument against related theories. The content validity is basically an opinion, in other words, the validation process in this study is done by collecting suggestions and opinions from experts qualitatively about the suitability of the indicators on the instrument with the theory.

The availability of validated instruments for the implementation of interactive multimedia learning is now quite necessary, seeing the trend of interactive multimedia development research starting to emerge. It is hoped that from the development of validated instruments for implementing the interactive multimedia learning plan, it can be an alternative for other development researchers to carry out the validation process of their learning tools.

\section{METHOD}

This research is a research development in the activity of standardizing instruments. As for the development steps are as follows (1) formulating the theoretical aspects of the learning plan developed; (2) compiling instrument lattices; (3) arranging instrument items; (4) drafting scoring rubrics and instrument criteria; (5) conducting expert judgment; (6) revision and improvement of instruments. The development of this instrument was carried out at the University of Nusantara PGRI Kediri with the help of instructional teaching learning and media expert.

\section{RESUlT AND DISCUSSION}

The preparation and development of learning plan implementation validation instruments use a theoretical development model, meaning that products or instruments are developed based on relevant theories and tested for suitability by the expert validator [8]. Sequentially the development activities will be described in stages as below.

\section{A. Formulating Theoretical Aspects of developing Learning Plans}

\section{1) Aspects of Learning Implementation Plans}

The learning implementation plan can be interpreted as a short-term learning plan for the achievement of a basic competency [9]. The learning implementation plan is compiled based on basic competencies or sub-themes carried out one or more meetings lesson. In this development plan drawn up in low-grade primary school, so that the implementation plan arranged in one sub-theme.

The learning implementation plans development process is very necessary to assist in defining the implementation of learning, that the development of learning is the process of mixing procedures and using them optimally to create new learning in certain situations [9]. learning implementation plans are planning programs that are prepared as guidelines for the implementation of learning for each learning process activity [10].

The learning implementation plan of learning developed in Indonesia must at least be based on the Minister of Education and Culture Regulation of the Republic of Indonesia Number 22 the Year 2016 concerning the Standard Process for Primary and Secondary Education. Regulations governing the learning implementation plan are arranged in chapter III of this regulation, which is about the minimum components and principles of the preparation of learning implementation plan

The components of the implementation plan for learning that have been conditioned for low-grade elementary school are as follows: (1) School identity, (2) themes and subthemes, (3) class and semester, (4) subject matter, (5) time allocation, (6) basic competencies, (7) competency achievement indicators, (8) learning objectives, (9) learning material, (10) learning methods, (11) learning media, (12) learning resources, (13) learning steps, and (14) learning assessment. Then the principles of learning implementation plans include: (1) paying attention to individual differences in students, (2) active participation of students, (3) centering on students, (4) developing a culture of reading and writing, (5) providing feedback and follow-up, (6) linkages and integration between basic competencies, learning material, learning activities, indicators of achievement of competence, assessment, and learning resources in one whole learning experience, (7) accommodating thematic-integrated learning, cross-subject integration, cross-learning aspects and cultural diversity, (8) the application of information and communication technology in an integrated, systematic and effective manner.

\section{2) Aspects of Stages Multimedia-Based Learning}

The meaning of multimedia is the use of various types of media (text, sound, graphics, video, animation) [11]. Multimedia can attract more senses and attract interest because it is a combination of views, sounds, and movements. Computer research and publishing institutions, 
namely computer technology research (CTR) states that people can only remember $20 \%$ of what they see and $30 \%$ of what they hear, but people can remember $50 \%$ of what they see and hear and $80 \%$ of what they see, hear and carried out at once (in Praherdhiono) [12]. In line with that according to Ariani [13] learning to use multimedia will be more interesting, more interactive, the amount of lecture time can be reduced, students' attitudes and learning attention are increased and centered, and the quality of learning can be more motivated.

In order to implement this learning plan, the conditions coexist with interactive multimedia, so, the development of the learning implementation plan must contain five steps of cognitive multimedia learning theory according to Mayer [5]. In order for learning in an interactive multimedia environment to occur meaningfully, students must engage in five cognitive processes: (1) choose words that are relevant for processing in verbal working memory, (2) select relevant images for processing in memory visual work, (3) arranging selected words into mental verbal models, (4) arranging selected images into mental visual models, and (5) combining verbal and visual representations with preexisting knowledge[5].

Still according to Mayer [5], the five stages above, although arranged in a list, in reality, do not have to occur in a linear sequence. The following are the stages that are presented by Mayer [5].

a) Select the relevant word (audio/text). At this stage, multimedia-based learning is feasible, there is an activity to deliver messages in the form of spoken sounds from multimedia and then received by students or text that appears from multimedia then received by students. This means that in the learning step there must be a stage of observing /paying attention to words (whether in the form of sound or text) from this multimedia.

b) Select relevant images. At this stage, multimediabased learning is feasible, there are activities in the form of the appearance of images from multimedia received by students. This means that in the learning step there must be a stage of observing the images of this multimedia. This observation stage is the same as the previous stage, which is accepting an object, but the object received is different, namely before is the words in the form of sound or text and at this time are pictures. But it should be noted, this stage does not have to be sequential or even appear at once, namely words in the form of sound or text and images appearing simultaneously and received and by students simultaneously.

c) Arrange selected words. After students hear information in the form of sound and or read information in the form of text, the next step is to organize the information into structured information. At this stage occurs in the working memory of the student's brain, meaning that observation of the process is very difficult to observe, therefore, as a solution, students are asked to ask questions from the information that has been collected. These questions can be implemented in multimedia directly or require additional paper-based, such as worksheets that accompany the learning process of students using multimedia. d) Arrange selected images. Just like the previous stage, the object at this stage is the pictures, while the process also occurs in the working memory structure of the student's brain, so that it is difficult to observe, so to ensure this process is carried out it needs a questioning activity whose implementation is like in the previous stage. The stage of arranging images and arranging words can also occur at once.

e) Integrating word-based representations (audio/text) and images. According to Mayer [5], the most important step of implementing multimedia learning is the stage of combining words (audio/text) and images. In addition, this stage does not rule out the possibility of involving prior knowledge (knowledge not obtained from information on multimedia). Can be interpreted, at this stage will be achieved if students who use interactive multimedia can deduce from various information (text/audio and images) that they observe. In addition, this stage can also be measured if students can answer questions about the conclusions of information that has emerged in multimedia.

\section{B. Arranging Instrument Lattice}

After formulating the aspects of the instrumented compiler above, the next step is to arrange the instrument lattice. The following are described in the instrument grid below.

TABLE I. INSTRUMENT LATTICE

\begin{tabular}{|c|c|c|}
\hline Aspect & Number & Indicator \\
\hline \multirow{13}{*}{$\begin{array}{l}\text { Components of } \\
\text { the Learning } \\
\text { Implementation } \\
\text { Plan }\end{array}$} & 1 & Contain school identity \\
\hline & 2 & $\begin{array}{l}\text { Contains theme and subtheme } \\
\text { information }\end{array}$ \\
\hline & 3 & $\begin{array}{l}\text { Contains information about the } \\
\text { class and the semester }\end{array}$ \\
\hline & 4 & $\begin{array}{l}\text { Contains information on the subject } \\
\text { matter that corresponds to the } \\
\text { subjects in the teacher's book or a } \\
\text { theme/sub-theme mapping net for the } \\
\text { learning }\end{array}$ \\
\hline & 5 & $\begin{array}{l}\text { Contains time } \\
\text { allocation information for } 1 \text { day of } \\
\text { learning }\end{array}$ \\
\hline & 6 & $\begin{array}{l}\text { Contains appropriate basic } \\
\text { competency } \\
\text { information teacher's book or theme / } \\
\text { sub-mapping mapping net for the } \\
\text { learning }\end{array}$ \\
\hline & 7 & $\begin{array}{l}\text { Contains information indicator of } \\
\text { achievement of appropriate } \\
\text { competencies teacher's book or } \\
\text { theme / sub-mapping net for the } \\
\text { learning }\end{array}$ \\
\hline & 8 & $\begin{array}{l}\text { Contains information learning } \\
\text { objectives that use operational and } \\
\text { measurable verbs that include } \\
\text { attitudes, knowledge, and skills }\end{array}$ \\
\hline & 9 & $\begin{array}{l}\text { Contains information on learning } \\
\text { material that contains relevant facts, } \\
\text { concepts, principles, and procedures, } \\
\text { and is written in the form of items in } \\
\text { accordance with the formulation of } \\
\text { competency indicators }\end{array}$ \\
\hline & 10 & $\begin{array}{l}\text { Contains information on learning } \\
\text { methods }\end{array}$ \\
\hline & 11 & Contains learning media information \\
\hline & 12 & $\begin{array}{l}\text { Contains information on learning } \\
\text { resources }\end{array}$ \\
\hline & 13 & Contains information on learning \\
\hline
\end{tabular}




\begin{tabular}{|c|c|c|}
\hline Aspect & Number & Indicator \\
\hline & & $\begin{array}{l}\text { steps through the introduction, core } \\
\text { and closing stages }\end{array}$ \\
\hline & 14 & $\begin{array}{l}\text { Contains information on assessment } \\
\text { of learning outcomes about } \\
\text { procedures, techniques, and forms of } \\
\text { assessment instruments }\end{array}$ \\
\hline \multirow[t]{8}{*}{$\begin{array}{l}\text { Principle } \\
\text { Learning } \\
\text { Implementation } \\
\text { Plan }\end{array}$} & 1 & $\begin{array}{l}\text { The design of learning allows } \\
\text { learning activities that pay } \\
\text { attention to individual differences in } \\
\text { students }\end{array}$ \\
\hline & 2 & $\begin{array}{l}\text { The design of learning allows } \\
\text { learning activities that involve the } \\
\text { active participation of students }\end{array}$ \\
\hline & 3 & $\begin{array}{l}\text { The learning design allows learner- } \\
\text { centered learning activities }\end{array}$ \\
\hline & 4 & $\begin{array}{l}\text { The design of learning allows } \\
\text { learning activities that develop a } \\
\text { culture of reading and writing }\end{array}$ \\
\hline & 5 & $\begin{array}{l}\text { The learning design } \\
\text { includes feedback and follow-up } \\
\text { activities }\end{array}$ \\
\hline & 6 & $\begin{array}{l}\text { All components of the learning } \\
\text { design are interrelated and integrated } \\
\text { into the integrated of the learning } \\
\text { experience }\end{array}$ \\
\hline & 7 & $\begin{array}{l}\text { The design of } \\
\text { learning accommodates thematic- } \\
\text { integrated learning }\end{array}$ \\
\hline & 8 & $\begin{array}{l}\text { Application of information and } \\
\text { communication technology in an } \\
\text { integrated, systematic and effective } \\
\text { manner }\end{array}$ \\
\hline \multirow[t]{5}{*}{$\begin{array}{l}\text { Stages of } \\
\text { Multimedia } \\
\text { Learning }\end{array}$} & 1 & $\begin{array}{l}\text { There are stages of observing } \\
\text { information in the form of words in } \\
\text { multimedia (both in the form of } \\
\text { sound and text) }\end{array}$ \\
\hline & 2 & $\begin{array}{l}\text { There are stages of observing } \\
\text { information in the form of images on } \\
\text { multimedia (both images that appear } \\
\text { permanently or move / animation) }\end{array}$ \\
\hline & 3 & $\begin{array}{l}\text { There are stages of processing } \\
\text { information in the form of words in } \\
\text { multimedia (both in the form of } \\
\text { sound and text) }\end{array}$ \\
\hline & 4 & $\begin{array}{l}\text { There are stages of processing } \\
\text { information in the form of images on } \\
\text { multimedia (both images that appear } \\
\text { regularly or move / animation) }\end{array}$ \\
\hline & 5 & $\begin{array}{l}\text { There are stages of combining } \\
\text { information representation of words } \\
\text { (voice and text) and images with pre- } \\
\text { existing knowledge }\end{array}$ \\
\hline
\end{tabular}

\section{Compile Instrument Items}

Instrument items are developed based on instrument lattice. These instrument items must use the most operational words possible. Instrument items can be seen below.

\section{TABLE II. ASPECTS OF COMPONENTS OF} THE LEARNING IMPLEMENTATION PLAN

\begin{tabular}{|c|l|}
\hline Number & \multicolumn{1}{c|}{ Statement Item } \\
\hline 1 & $\begin{array}{l}\text { In the learning implementation plan, there is clear } \\
\text { information on school identity }\end{array}$ \\
\hline 2 & $\begin{array}{l}\text { In the learning implementation plan, there is a clear theme } \\
\text { and sub-information }\end{array}$ \\
\hline 3 & $\begin{array}{l}\text { In the learning implementation plan, there is complete } \\
\text { class and semester information }\end{array}$ \\
\hline 4 & $\begin{array}{l}\text { In the learning implementation plan, there is basic } \\
\text { material information that is detailed according to the } \\
\text { subjects used }\end{array}$ \\
\hline 5 & In the learning, implementation plan contains information \\
\hline
\end{tabular}

\begin{tabular}{|c|c|}
\hline Number & Statement Item \\
\hline & on time allocation for 1 day of learning \\
\hline 6 & $\begin{array}{l}\text { In the learning implementation plan, there is basic } \\
\text { competency information that matches the teacher's book } \\
\text { or the theme / sub-mapping mapping net for the learning }\end{array}$ \\
\hline 7 & $\begin{array}{l}\text { In the learning, implementation plan contains basic } \\
\text { competency information consisting of basic competencies } \\
\text { of knowledge and skills }\end{array}$ \\
\hline 8 & $\begin{array}{l}\text { In the learning, implementation plan contains information } \\
\text { on indicators of achievement of competencies that } \\
\text { correspond to the teacher's book or the theme / sub-theme } \\
\text { mapping net of the learning }\end{array}$ \\
\hline 9 & $\begin{array}{l}\text { In the learning, implementation plan contains information } \\
\text { on competency achievement indicators which consist of } \\
\text { the development of basic competencies of knowledge and } \\
\text { skills }\end{array}$ \\
\hline 10 & $\begin{array}{l}\text { In the learning, implementation plan contains information } \\
\text { on learning objectives that use operational verbs and can } \\
\text { be measured }\end{array}$ \\
\hline 11 & $\begin{array}{l}\text { In the learning, implementation plan contains information } \\
\text { on learning objectives that include attitudes, knowledge, } \\
\text { and skills }\end{array}$ \\
\hline 12 & $\begin{array}{l}\text { In the learning, implementation plan contains information } \\
\text { on learning objectives consisting of ABCD (audience, } \\
\text { behavior, condition, and degree) }\end{array}$ \\
\hline 13 & $\begin{array}{l}\text { In the learning, implementation plan contains information } \\
\text { on learning material that contains facts, concepts, } \\
\text { principles, and procedures that are relevant (can be placed } \\
\text { in the attachment) }\end{array}$ \\
\hline 14 & $\begin{array}{l}\text { In the implementation plan, learning contains information } \\
\text { on learning material arranged in the form of items that are } \\
\text { in accordance with the formulation of competency } \\
\text { indicators (can be placed in the attachment) }\end{array}$ \\
\hline 15 & $\begin{array}{l}\text { In the learning, implementation plan contains } \\
\text { comprehensive learning method information according to } \\
\text { the learning steps }\end{array}$ \\
\hline 16 & $\begin{array}{l}\text { In the learning, implementation plan contains complete } \\
\text { learning media information }\end{array}$ \\
\hline 17 & $\begin{array}{l}\text { In the learning, implementation plan contains information } \\
\text { on learning resources }\end{array}$ \\
\hline 18 & $\begin{array}{l}\text { The learning implementation plan contains learning steps } \\
\text { through introduction activities which include: (1) } \\
\text { preparing students physically and psychologically, (2) } \\
\text { motivating contextually according to the benefits of } \\
\text { teaching materials, (3) giving apperception, (4) explaining } \\
\text { learning objectives, (5) convey the scope of the material, } \\
\text { (6) deliver a description of learning activities }\end{array}$ \\
\hline 19 & $\begin{array}{l}\text { In the learning, implementation plan contains steps of } \\
\text { learning through the stages of the core activities which } \\
\text { include the affection process starting from accepting, } \\
\text { running, appreciating, appreciating, to practicing a } \\
\text { predetermined attitude }\end{array}$ \\
\hline 20 & $\begin{array}{l}\text { In the learning implementation plan contains steps of } \\
\text { learning through the stages of the core activities which } \\
\text { include the process of acquiring knowledge through } \\
\text { activities of knowing, understanding, implementing, } \\
\text { analyzing, evaluating, and creating }\end{array}$ \\
\hline 21 & $\begin{array}{l}\text { In the learning implementation plan contains steps of } \\
\text { learning through the stages of the core activities which } \\
\text { include the process of acquiring skills through observing, } \\
\text { asking, trying, reasoning, presenting, and creating }\end{array}$ \\
\hline 22 & $\begin{array}{l}\text { In the learning implementation plan contains steps of } \\
\text { learning through the stages of the closing activities which } \\
\text { include: (1) activities to find direct or indirect benefits } \\
\text { from the learning outcomes that have taken place, (2) } \\
\text { activities to provide feedback on learning processes and } \\
\text { outcomes, (3) conduct follow-up in the form of } \\
\text { assignments, both individually and in groups, (4) inform } \\
\text { the planned learning activities for the next meeting }\end{array}$ \\
\hline 23 & $\begin{array}{l}\text { The learning implementation plan contains assessment } \\
\text { information on learning outcomes about procedures, } \\
\text { techniques, and forms of assessment }\end{array}$ \\
\hline 24 & $\begin{array}{l}\text { In the learning, implementation plan contains procedures } \\
\text { for evaluating processes and results }\end{array}$ \\
\hline 25 & $\begin{array}{l}\text { In the learning, implementation plan contains a form of } \\
\text { assessment that measures the aspect of attitude (in the }\end{array}$ \\
\hline
\end{tabular}




\begin{tabular}{|c|l|}
\hline Number & \multicolumn{1}{|c|}{ Statement Item } \\
\hline 26 & $\begin{array}{l}\text { attachment) } \\
\text { assessment that measures aspects of knowledge (in the } \\
\text { attachment) }\end{array}$ \\
\hline 27 & $\begin{array}{l}\text { In the implementation plan, learning contains a form of } \\
\text { assessment that measures aspects of skills (in the } \\
\text { attachment) }\end{array}$ \\
\hline
\end{tabular}

TABLE III

ASPECTS OF THE PRINCIPLES OF LEARNING IMPLEMENTATION PLANS

\begin{tabular}{|c|l|}
\hline Number & \multicolumn{1}{|c|}{ Statement Item } \\
\hline 1 & $\begin{array}{l}\text { The whole learning design allows learning activities that } \\
\text { pay attention to individual differences in students which } \\
\text { includes the potential, abilities, special needs and } \\
\text { environment of students }\end{array}$ \\
\hline 2 & $\begin{array}{l}\text { Full learning design allows learning activities that involve } \\
\text { the active participation of students }\end{array}$ \\
\hline 3 & Full learning design allows learner-centered activities \\
\hline 4 & $\begin{array}{l}\text { Full learning design allows learning activities that develop } \\
\text { a culture of reading and writing }\end{array}$ \\
\hline 5 & $\begin{array}{l}\text { The learning plan contains feedback and follow-up } \\
\text { activities }\end{array}$ \\
\hline 6 & $\begin{array}{l}\text { The whole component of learning design is interrelated } \\
\text { and integrated into one whole learning experience }\end{array}$ \\
\hline 7 & $\begin{array}{l}\text { The design of learning accommodates thematic-integrated } \\
\text { learning }\end{array}$ \\
\hline 8 & $\begin{array}{l}\text { Application of information and communication } \\
\text { technology in an integrated, systematic and effective } \\
\text { manner }\end{array}$ \\
\hline
\end{tabular}

TABLE IV.

ASPECTS OF THE STAGES OF MULTIMEDIA LEARNING

\begin{tabular}{|c|l|}
\hline Number & \multicolumn{1}{|c|}{ Statement Item } \\
\hline 1 & $\begin{array}{l}\text { There is an act of observing information in the form of } \\
\text { words on multimedia (both in the form of sound and text) } \\
\text { carried out by students }\end{array}$ \\
\hline 2 & $\begin{array}{l}\text { There is an act of observing information in the form of } \\
\text { pictures on multimedia (both images that appear regularly } \\
\text { or in motion/animation) carried out by students }\end{array}$ \\
\hline 3 & $\begin{array}{l}\text { There is a questioning activity from information in the } \\
\text { form of words in multimedia (both in the form of sound } \\
\text { and text) }\end{array}$ \\
\hline 4 & $\begin{array}{l}\text { There is a questioning activity from information in the } \\
\text { form of images on multimedia (both images that appear } \\
\text { regularly or move / animation) }\end{array}$ \\
\hline 5 & $\begin{array}{l}\text { There are activities to integrate and conclude information } \\
\text { from words (voice and text) and images with pre-existing } \\
\text { knowledge }\end{array}$ \\
\hline
\end{tabular}

D. Compile A Scoring Rubric and Instrument Validity Criteria

For each item, the statement has five answer choices that are adjusted to a Likert scale that is very inappropriate (STS) not suitable (TS), less appropriate (KS), appropriate (S), very appropriate (SS). Scoring for each answer has a score of 1 for STS, 2 for TS, 3 for KS, 4 for S, and 5 for SS. From the scoring guidelines above, the valuation calculation uses the formula

$$
\text { Value }=\frac{\text { एacquisition score }}{\text { ¿statement item }}
$$

The instrument criteria are divided into 5 levels with criteria that can be observed in the table below.

TABLE V

VALIDITY LEVEL CRITERIA TABLE

\begin{tabular}{|c|c|c|}
\hline Number & $\begin{array}{c}\text { Validity } \\
\text { Criteria }\end{array}$ & Validity Level \\
\hline 1 & $\mathrm{X}=5$ & Very valid, can be used without revision \\
\hline 2 & $4 \geq \mathrm{X}<5$ & Valid can be used with minor revisions \\
\hline 3 & $3 \geq \mathrm{X}<4$ & Less valid recommended not to be used, \\
\hline
\end{tabular}

\begin{tabular}{|c|c|l|}
\hline Number & $\begin{array}{l}\text { Validity } \\
\text { Criteria }\end{array}$ & \multicolumn{1}{c|}{ Validity Level } \\
\hline & & moderate revision \\
\hline 4 & $2 \geq \mathrm{X}<3$ & Invalid, large revisions, should not be used \\
\hline 5 & $1 \geq \mathrm{X}<2$ & $\begin{array}{l}\text { Very invalid, should not be used, total } \\
\text { revision }\end{array}$ \\
\hline
\end{tabular}

The scoring guide above is informed at the beginning of the questionnaire instrument (placed in the instructions section) which is developed so that the validator can read it at the beginning of reading this instrument. Then for the formula and criteria, the level of validity is placed at the end after the items are displayed.

\section{E. Conducting Expert Judgment}

After the statement item at the expert validation stage is completed, it is necessary to conduct an assessment by an expert. To facilitate the expert to conduct an assessment and input on this instrument a specific guide is used. As for the guide along with the results obtained from the validation assistance by Dr. Zainal Afandi (University of Nusantara PGRI Kediri) can be observed as follows:

\section{TABLE VI. INSTRUMENT ASSESSMENT GUIDE}

\begin{tabular}{|c|c|c|c|c|c|}
\hline \multirow{2}{*}{ No } & \multirow{2}{*}{$\begin{array}{c}\text { Assessment } \\
\text { Aspect }\end{array}$} & \multicolumn{3}{|c|}{ Judging } & \multirow{2}{*}{$\begin{array}{c}\text { Feedback / } \\
\text { Suggestions / } \\
\text { Opinions }\end{array}$} \\
\hline & & Less & Enough & Good & \\
\hline 1 & $\begin{array}{l}\text { The practicality } \\
\text { of instrument } \\
\text { use instructions }\end{array}$ & & & $\sqrt{ }$ & $\begin{array}{l}\text { Instructions for } \\
\text { use are easy to } \\
\text { understand, clear } \\
\text { and detailed }\end{array}$ \\
\hline 2 & $\begin{array}{l}\text { Suitability of } \\
\text { the theoretical } \\
\text { definition } \\
\text { aspects of } \\
\text { the components } \\
\text { of the learning } \\
\text { implementation } \\
\text { plan studied }\end{array}$ & & & $\sqrt{ }$ & $\begin{array}{l}\text { - Theoretical } \\
\text { study on the } \\
\text { components of the } \\
\text { implementation } \\
\text { plan of learning } \\
\text { that has been } \\
\text { studied is } \\
\text { appropriate } \\
\text { because it directly } \\
\text { refers to the } \\
\text { regulations of the } \\
\text { Minister of } \\
\text { Education and } \\
\text { Culture } \\
\text { - The formulation } \\
\text { of the grid and its } \\
\text { instruments have } \\
\text { been described in } \\
\text { such a way that it } \\
\text { can be observed in } \\
\text { detail }\end{array}$ \\
\hline 3 & $\begin{array}{l}\text { Suitability of } \\
\text { the theoretical } \\
\text { definition of } \\
\text { the principal } \\
\text { aspects of the } \\
\text { learning } \\
\text { implementation } \\
\text { plan studied }\end{array}$ & & & $\sqrt{ }$ & $\begin{array}{l}\text { - Theoretical } \\
\text { study on the } \\
\text { principle of the } \\
\text { implementation } \\
\text { plan of learning } \\
\text { that has been } \\
\text { studied is } \\
\text { appropriate } \\
\text { because it directly } \\
\text { refers to the } \\
\text { regulation of the } \\
\text { Minister of } \\
\text { Education and } \\
\text { Culture. } \\
\text { - The } \\
\text { formulation of the } \\
\text { grid and its } \\
\text { instruments have }\end{array}$ \\
\hline
\end{tabular}




\begin{tabular}{|c|c|c|c|c|c|}
\hline \multirow[b]{2}{*}{ No } & \multirow{2}{*}{$\begin{array}{c}\text { Assessment } \\
\text { Aspect }\end{array}$} & \multicolumn{3}{|c|}{ Judging } & \multirow{2}{*}{$\begin{array}{c}\text { Feedback / } \\
\text { Suggestions / } \\
\text { Opinions }\end{array}$} \\
\hline & & Less & Enough & Good & \\
\hline & & & & & $\begin{array}{l}\text { been described in } \\
\text { such a way that it } \\
\text { can be observed } \\
\text { easily }\end{array}$ \\
\hline 4 & $\begin{array}{l}\text { The suitability } \\
\text { of the } \\
\text { theoretical } \\
\text { study of aspects } \\
\text { of the stages of } \\
\text { learning based } \\
\text { on multimedia } \\
\text { learning is } \\
\text { assessed }\end{array}$ & & & $\sqrt{ }$ & $\begin{array}{l}\text { Theoretical } \\
\text { studies on aspects } \\
\text { of the stages of } \\
\text { multimedia } \\
\text { learning based } \\
\text { learning are in } \\
\text { accordance with } \\
\text { the theory. } \\
\text { Adjustments to } \\
\text { operational } \\
\text { statements may } \\
\text { have been made }\end{array}$ \\
\hline 5 & $\begin{array}{l}\text { Suitability of } \\
\text { the } \\
\text { development of } \\
\text { the grid and } \\
\text { statement items } \\
\text { with theoretical } \\
\text { studies }\end{array}$ & & & $\sqrt{ }$ & $\begin{array}{l}\text { Overall the grid } \\
\text { and statement } \\
\text { items are in } \\
\text { accordance with } \\
\text { the theory }\end{array}$ \\
\hline 6 & $\begin{array}{l}\text { Operational } \\
\text { level statement } \\
\text { items }\end{array}$ & & & $\sqrt{ }$ & $\begin{array}{l}\text { Statement items } \\
\text { have been made } \\
\text { as operational as } \\
\text { possible }\end{array}$ \\
\hline 7 & $\begin{array}{l}\text { Representative } \\
\text { distribution of } \\
\text { items }\end{array}$ & & & $\sqrt{ }$ & $\begin{array}{l}\text { The item } \\
\text { distribution of } \\
\text { statement items } \\
\text { represents the grid } \\
\text { on the aspects that } \\
\text { have been } \\
\text { formulated }\end{array}$ \\
\hline 8 & $\begin{array}{l}\text { Suitability of } \\
\text { scale selection }\end{array}$ & & & $\sqrt{ }$ & $\begin{array}{l}\text { The scale } \\
\text { selection is in } \\
\text { accordance with } \\
\text { the rules }\end{array}$ \\
\hline 9 & $\begin{array}{l}\text { Suitability of } \\
\text { the formula } \\
\text { used }\end{array}$ & & & $\sqrt{ }$ & $\begin{array}{l}\text { The formula used } \\
\text { is appropriate and } \\
\text { can be } \\
\text { synchronized with } \\
\text { guidelines and } \\
\text { criteria for scoring }\end{array}$ \\
\hline 10 & $\begin{array}{l}\text { Suitability of } \\
\text { guidelines and } \\
\text { criteria for } \\
\text { scrutiny }\end{array}$ & & & $\sqrt{ }$ & $\begin{array}{l}\text { The guidelines } \\
\text { and criteria for } \\
\text { depositing used } \\
\text { are in accordance } \\
\text { with the formulas } \\
\text { and rules of the } \\
\text { questionnaire } \\
\text { instrument }\end{array}$ \\
\hline
\end{tabular}

\section{F. Revision and Improvement of Instrument}

In general, the results of validation by experts can be said to be good and instruments can be used. Even though according to the expert, this instrument is said to be good and can be used but on the next occasion a more objective assessment rubric needs to be developed. For example what conditions to get a score of $5,4,3,2$ or 1 . In addition, other aspects besides the theoretical aspects examined above, other aspects need to be developed, such as aspects of value education, scientific aspects of learning, and developmental aspects of students in the implementation plan of learning.

\section{CONCLUSION}

Based on the results of the study and discussion can be taken as follows: (1) Based on a theoretical study, three aspects of the theoretical foundation were formulated as the ingredients for the instrument, namely (a) aspects of the components of the learning implementation plan, (b) the principle aspects of the learning implementation plan, (c ) aspects of the stages of multimedia learning. (2) Based on the results of content validation by instrument experts can be said to have good categories, and can be used.

\section{ACKNOWLEDGMENT}

The research team expressed their sincere gratitude to all those who helped to publish this paper. The researcher also expressed his gratitude to the University of Nusantara PGRI Kediri for supporting this research activity. Specifically, thanks to the Directorate of Industrial Technology Development, Directorate General of Research and Development Strengthening, Ministry of Research, Technology and Higher Education Indonesia which has supported this research through funding program grant "Insentif Riset Sistem Inovasi Nasional (INSINAS)".

\section{REFERENCES}

[1] Nielsen, “The New Trend Among Indonesia's Netizens How and where digital consumers are watching content online", (Online), (https://kupdf.com/download/nielsen-indonesia-digital-consumer26072017pdf_5a8abfdde2b6f5cd431d6571_pdf), accessed on March 2017, 2017

[2] C. Sterbenz, "Here's who comes after Generation Z-and they'll be the most transformative age group ever", Businessinsider, (Online), (http://www.businessinsider.com/generation-alpha-2014-7-2), accessed on March 2017, 2015

[3] K. A. Aka, "Pemanfaatan Teknologi Informasi dan Komunikasi (TIK) Sebagai Wujud Inovasi Sumber Belajar di Sekolah Dasar”, ELSE (Elementary School Education Journal): Jurnal Pendidikan dan Pembelajaran Sekolah Dasar, 1(2a), 2017

[4] Minister of Education and Culture Regulation of the Republic of Indonesia Number 22 of 2016 concerning Standard Process of Primary and Secondary Education

[5] R. E. Mayer, "Multimedia Learning", United States of America: Cambride University Press, 2003

[6] F. N. Kerlinger, Foundation of Behavioral Research (Asas-asas penelitian behavioral). (Terjemahan Simatupang, Landung R. \& Koesoemanto, H.J.), Yogyakarta: Gama University Press, 1978

[7] K. Hidayati, Validasi Instrumen Non Tes dalam Penelitian Pendidikan Matematika, Prosiding Jurusan Pendidikan Matematika FMIPA UNY, 503-511, 2012

[8] K. Hidayati, E. Listyani, Pengembangan Instrumen Kemandirian Belajar Mahasiswa, Jurnal Penelitian dan Evaluasi Pendidikan, 14(1), 2010

[9] S. Akbar, Panduan Praktik Pengembangan RPP Berorientasi pada Pendidikan Karakter. Malang: Program Pascasarjana Universitas Kanjuruhan Malang, 2010

[10] W. Sanjaya, Kurikulum dan Pembelajaran. Jakarta: Kencana Prenada Media Group, 2010

[11] A. Setiawan, Dasar-dasar Multimedia Interaktif (MMI). Bandung: SPS UPI Bandung, 2007

[12] H. Praherdhiono, E. P. Adi, Panduan Praktikum Multimedia. Malang: FIP Universitas Negeri Malang, 2008

[13] N. Ariani, H. Dany, Pembelajaran Multimedia di Sekolah Pedoman Pembelajaran Inspiratif, Konstruktif, dan Prospektif. Jakarta: PT Prestasi Pustakarya, 2010 